\title{
Phonetic and Phonological Investigation of Tati Kajal Dialect (Khalkhal)
}

\author{
Mohammad Asadi \\ Department of Linguistics, Science and Research Branch, Islamic Azad University, Tehran, Iran \\ Mehdi Bagheri Hariry \\ Department of English Language, Science and Research Branch, Islamic Azad University, Tehran, Iran \\ Razzagh Kiyani \\ Department of Linguistics, Science and Research Branch, Islamic Azad University, Tehran, Iran
}

\begin{abstract}
This article is an attempt to investigate and describe Tati Kajal dialect of Khalkhal in Ardebil city that has not ever been studied thoroughly. The article studies the general Phonetic aspects of the dialect. The dialect is one of the dialects in the north-western Iran which has maintained its ancient characteristics and subsequently distinguished itself from Persian language. Some of the characteristics are as follows: ergative structure, passive voice, grammatical gender and mood. Phonetically speaking, in addition to all existing vowel and consonants in standard Persian the dialect also includes such phones as $\ddot{o}, \ddot{u}, \partial, \gamma$, but there is no glottal stop /?/ in Tati Kajal, because it doesn't have total distribution in the onset, nucleus and coda of the syllable but it is sometimes used as the middle phoneme. The dialect has kept the vowel $/-a /$ at the end of lexical morphemes and substitution of vowels in some of the verbs as well.
\end{abstract}

Index Terms - Tati, Tats, Khalkhal, Kajal, conversion, Elision, Epenthesis, Metathesis

\section{INTRODUCTION}

Dialectology is the search for spatially and geographically determined differences in various aspects of language. For each village or region that they study, dialectologists want to know the typical local vocabulary or pronunciation. As a result, their subjects of choice are usually older people who have lived all their lives in one location and who have had a minimum of education. Once found, they are quizzed by the fieldworker for names of objects or pronunciations of words or strange expressions. Careful plotting of different variants permits dialectologists to recognize major regional differences. Geographical differences continue to provide grist for the sociolinguistic mill, but the studies have become more complex as the influence of other factors has been accepted. A recent study of the Mexican-American border, for instance, indicates that distance from the border is indeed one of the explanations of Spanish language maintenance among people who have crossed into the United States, but that it needs to be set against other sociological factors such as education and mobility. Geographical space, in other words, is not enough to account for language variation. This becomes clear if we look at the regular discussion of the difference between a language and a dialect. From a linguistic point of view, regional dialects tend to show minor differences from their immediate neighbors, and greater differences from distant varieties. Thus, one can demonstrate the existence of a chain of dialects from Paris to Rome. At the FrancoItalian border, however, although there is no linguistic break in the chain, the political distinction is enough to make it clear that one has moved from dialects of French to dialects of Italian. The decision of what language a dialect belongs to is therefore social and political rather than purely linguistic. The kinds of differences in patterns of variation that are produced by geographical or special isolation are regularly transformed into powerful mechanisms for asserting and recognizing social differences.

Iranian languages and accents are precious treasures that represent the ancient and historical culture and civilization of the land, hence a scientific study and gathering or recording the words, phrases and idioms not only can revive languages and dialects, but also are preludes for other language related studies. Because of the fact that language of a nation reflects its culture, beliefs, conventions and historical background and exterminating it means to eliminate the cultural legacy of the society, the importance and usefulness of language researches seems more necessary. In order to prevent the language death a systematic attempt is required to investigate and describe native dialects and languages with their socio-cultural roles. The linguists of inside and outside the country have always considered the variety of Iranian dialects, the similarities and differences between Persian language and these dialects, the ancient Iranian languages and middle and modern periods. Despite the relationship between these languages, they are distinguished from each other and such a distinction is created based upon the principles of particular changes of each language in different periods and specific historical conditions of the people who speak in this language. Meanwhile, the investigation of commonalities and particular changes of Iranian languages in phonological, morphological and syntactic areas can help to study the linguistic problems including historical linguistic researches. 
Generally speaking, Tati dialects can be divided into two categories:

A) Northen Tati, B) Southern Tati.

A: The northen Tati is spoken in the following regions:

Daghestan (Darband), Northen-east of Azerbaijan Republic in Ghafghaz, Apshroun Peninsula, Baku, Surakhani, Balakhani, Mashtagha, Bouzona, Amirkhan, Daghestan Afroojeh and Darband Abshooran.

Northen Tati falls into several categories, namely 1) Muslim Tats,

2) Jewish Tats who call themselves "Dagh Joodi" (mountainous Jew) that often live in Daghestan, 3) Christian Armenian and Northen - east Azerbaijan Tats (Divichi, Lakhij and Apshroun Peninsula in eastern Baku) (Smith, 2004, P.489).

B: Southern Tati is spoken in different regions of Iran such as:

1) some areas in the south-west of Ghazvin including Takestani, Shali, Khiyarji, Ebrahim Abadi, Sagaz Abadi, Dansefani, Esfarorini and Khoznini varieties (Yarshater, 1969, PP.17-18). 2) Eshtehard of Karaj (ibid.).

3) Khalkhal: Including Eskestani, Asbooi, Dervi, Koluri, Shali, Dizi, Karini, Kehli, Lerdi, Gilvani and Taharemdashti varieties in Shahrood and Kajali and Karanghi varieties in Khoreshrostam.

4) Zanjan: In Kholeen, sixty kilometers away from south-west of Zanjan Province and Taremelia (including Nokiani, Siavarodi, Hezarroodi, Jamalabadi, Baklouri, Kalesari and Shavaee Cherzehee Varieties) (ibid.:17).

5) Eastern Azerbaijan: Including Harzand, Dizmar, Karingan, Kalibar and other areas.

6) Roodbar, Alamout and foothill. In Jirandeh section of Roodbar, people in Nash, Estalkh mountain, chichal, Liavalelia, chalvan sar, Ghoshalaneh, Sepestanak, Garzanehchak, Koshkosh, Jalaldeh, Lyaval sefli and Barehsar Villages speak in Tati and in Farab section, people in Anbooh, Kelishom, Khormkooh, Viah, Navah, Layah, Nodeh farab and Yekunom villages speak in Tati as well.

7) Northen Khorasan, Shoghan Plain and the region of chardah Sankhoast (Safarzadeh, 2003, P.23).

In some regions of Iran there are some people who consider their language as Tati, but their claim can not be taken as valid since the geographical distribution of Tati language can be depicted and completed just on the basis of scientific research and true linguistic characteristics.

It is worth mentioning that the village is situated eighty kilometers away from Khalkhal in Khoreshrostam region that is one of the provincial towns of Khalkhal and the people in all surrounding villages speak in Turkish.

In spite of the fact that this dialect is surrounded by Turkish speaking communities, it has not been influenced by that language and has always been resistant; however, it is on the verge of extinction like never before. There are some reasons involved the most important of which is the attitude of people specially that of the young couples towards their mother tongue. Actually, such people have a negative attitude to Tati dialect and always try to speak in Persian. On the other hand, the young people of this village migrate to other cities in search of work and the only people who remain here are the elderly who speak in Tati and that is why the dialect is threatened with extinction and undoubtedly will have no speaker in the near future.

\section{Statement of the Problem:}

The present study attempts to final that how Tati Kajal behaves phonetically.

A review of the written books and articles that implicitly or explicitly address Tati dialect and critically study the language indicates that the dialect has not ever been investigated scientifically and there are many ambiguous aspects that require the ambition and desire of those linguists and Iranologists who are interested in Iranian identity. It may be possible to say that Ahmad Kasravi was one who first introduced Tati seriously and argued about "Azeri Language". In fact, the book "Azeri or the Ancient Language of Azerbaijan" that was written more than eighty years ago was a beginning for different scientific and non-scientific debates between Azeri adherents and the followers of "Turks Immigration to Azerbaijan" hypothesis in one hand and those who deny the language as well as those who believe that Turk language has its origins in Azerbaijan on the other hand. The following people critically pursued Kasravi's thoughts: Mohammadamin Adib Tusi, Reza Malekzadeh, Manoochehr Mortazavi, Yahya Zoka, Ehsan Yarshater, Abbas Eghbal Ashtiani, Fereydoun Joneydi, Manoochehr Sotoudeh, Rashid Eyvazi, Jamaloddin Faghih, Mohammad Ghazvini, Hosseinali Katebi, Yahya Mahyar Navvabi, Mohammadmohit Tabatabaea, Mohammad Moghaddam, Naseh Nategh and Saeed Nafisi, etc; However, a few of them directly addressed Tati and the history, culture and demography of Tatis. But, the following points are important about Tati Khalkhal; The dialect is common in two sections, namely A: Shahrud section, and B: Khoresh Rostam section. Tati in Khoresh Rostam section of Khalkhal is spoken in two villages, namely Kajal and Karnagh that are ninety kilometres away from each other and are mainly different in terms of dialect so that most of the times they hardly understand each other. Meanwhile, Tati Kajal is so different from Tati Shahrud. There are some researches about Tati kajal dialect (that is the subject of the present study) including, an article named "The Tati Dialect of Kajal" and a thesis titled "The Phonological Investigation of Tati Kajal Dialect Based on Modern Linguistic Methods", by Mari Aradgoli, under Dr. Seyfollah Najmabadi supervision (unpublished M.A. thesis, Tehran, 1971). It was then that the dialect was comprehensively studied. In addition to field works there are references that can be used for description and investigation of the dialect. The following studies on Tati Khalkhal have led up to compilation of some works that can be used as literature:

1. Yahyazadeh, Akbar (2004). The Linguistic Investigation of Tati Shahrud Khalkhal Dialect. (Unpublished M.A. Thesis). Under Dr. Mohmoodreza Dastgheyb Beheshti supervision. Shiraz University. 
2. Meraji Lord, Javad (1999). Tati Language in Shahrud Khalkhal. (Unpublished M.A. Thesis). Under Dr. Barat Zanjani supervision. Tehran Azad University, Central Branch.

3. Poordad, Mansoureh (1970). Tati Dialect from Azeri Language. (Unpublished B.A. Project). Tehran University.

4. Iranikolour, Adel (2002). Tati Grammar. Ardebil, Azerbaijan.

5. Aradgoli, Mari (1971). The Phonological Investigation of Tati Kajal Dialect Based on Modern Linguistic Methods. (Unpublished M.A. Thesis). Under Dr. Seyfollah Najmabadi supervision. Tehran University.

6. Sabzalipour, Jahandoost (2010). A Contrastive Analysis of Verb Structure in Taleshi, Tati Khalkhal and Gilaki Dialects. (Unpublished Ph.D. Dissertation). Under Dr. Moharam Rezayati supervision. Gilan University.

7. Yarshater, Ehsan (1960). The Tati Dialect of Kajal. BSOAS, 23.

8. ... (1959). The Dialect of Shahrudi (khalkhal). BSOAS, 22.

9. ... (1969). A Grammar of Southern Tati Dialects. The Hague, Paris.

\section{Research Question:}

Is Tati Kajal dialect different from Persian Phonetically as well as phonologically?

Research Hypothesis:

Tati Kajal is different from Persian Phonetically as well as phonologically.

\section{Methodology}

Since the research investigates Tati Kajal dialect, the methodology of conducting the research is that of descriptive that is performed in the modern linguistic theoretical frameworks and the data were gathered in two different ways. In diachronic studies the research used library method and in synchronic studies of the dialect both library and field works were used. In diachronic studies after studying every subject area related reference, the researcher provided note-cards and in synchronic studies the speakers of the mentioned dialect were given some questionnaires or were interviewed.

\section{Background of the Study:}

There are various viewpoints about the historical background of the dialect and about whether Tati is a dialect or a language, but according to the researches done in the field by Iranian and foreign researchers, it is the remains of one of the ancient Iranian languages of western Iran which was once spoken in the entire Azerbaijan, Ghazvin, and Gilan. In fact, the problem is that the varieties of Tati dialect are so different that in spite of observable resemblances, one variety may not be understood at all in other Tati-governed region. That's why it can not be easily considered as an individual language. There are some researchers outside Iran who have studied Tati, including Oranski, Miler, Giger, Dren, Diakonov and Hening, but linguistically speaking, this dialect has not been studied comprehensively.

\section{RESULTS AND ANALYSIS}

Phonetic and Phonological Investigation:

1) Tati vowels: The dialect includes the following vowels:

1-1. Vocalic Phonemes: The vowels that have Phonological value in this dialect contain five short vowels (o - ö - ə $\mathrm{e}-\mathrm{a})$ and four long vowels ( $\mathrm{a}-\mathrm{i}-\mathrm{u}-\mathrm{u}$ ).

1-2. Diphthongs: These vowels do not have phonological value in Tati dialect, but only phonetic value. The most important Tati diphthongs are as follows:

$\begin{array}{lll}\text { /ey/ } & \text { beyna } & \text { (outside) } \\ \text { /ow/ } & \text { howlig } & \text { (sister) } \\ \text { /oy/ } & \text { hoy } & \text { (hey) } \\ \text { / ây/ } & \text { harây } & \text { (shout) } \\ \text { /ay/ } & \text { ay } & \text { (wow) }\end{array}$

1-3. Mid vowels: Like Persian and other Iranian dialects, this dialect has often a vowel between two morphemes or two adjoining consonants that is called mid-vowel. Some mid-vowels in the dialect are as follows:

[a]: as in jân -[a]-var (animal)

[e]: as in bâq-[e]-bân (gardener)

[i]: as in huš-[i]-yâr (conscious)

2) Tati consonants: Like standard persian, Tati Kajal dialect is composed of 23 consonants, but there is not any glottal stop /?/ in the dialect because it does not have total distribution in onset, nucleus and coda of a syllable, but it is sometimes used as mid-vowel.

The dialect has a fricative consonant instead that is known as voiced Malazi $/ \gamma /$. Similar to Persian, all consonants in Tati Kajal are articulated through egressive pulmonic airstream. i.e. exhalation. The phonemic characteristic of each of the Tati consonants is obtained compared to minimal pairs and all Kajal consonants might be appeared in onset, nucleus and coda. Each of the consonants has itself a group of phones that in spite of fundamental articulatory similarities have some differences that are not big enough to change the phonetic identity of the phonemes and cause semantic contrast.

3) Syllable structure: Again similar to Persian, the syllable in Tati dialect is a continual Phonetic chain with a structure of (c) v (c) (c) that is composed of one vowel and one to three consonants. Vowel is the centre or nucleus of the syllable and the rest is/are consonant (s). Since the onset in this dialect is a phonetic reality (not phonemic), there are 
some syllables without consonant, that is to say the vowels are found in the onset, nucleus and coda of the syllable. (Sabzalipour, 2010: 33).

4) Consonant clusters in the coda of the syllable:

Like Persian there are two adjoining consonants in Tati dialect; in other words, the longest syllable is that of (c) v (c) (c).

5) Phonetic Processes: In Tati dialect as in Persian there are some of these processes like the following:

5-1 Assimilation:

dasta $\longrightarrow$ dassa (handle)

be + har $\longrightarrow$ bahar (eat!)

5-2 Dissimilation:

muškel $\longrightarrow$ mušgel (difficult)

5-3 conversion: changing $r$ into $l$ in the following example:

anjir $\longrightarrow$ anjil (fig)

5-4 Elision: elision in the end of the word like the following:

Šâh $\longrightarrow$ šâ: (king)

5-5 Epenthesis: the addition of a sound to the middle of a word:

be + ši - yâ $\longrightarrow$ beššiya (she went)

5-6 Metathesis: a reversal in position of two adjoining sounds like $b$ and $r$ in the following:

tabriz $\longrightarrow$ tarbiz (the name of a city in Iran)

6) Phonetic differences between Tati dialect and standard Persian:

In the contrastive analysis of Tati dialect and standard Persian some Phonetic differences can be observed that are not comprehensive, but involve very limited words; therefore, there is not a general rule for them. Moreover, comparing the dialect with Persian language does not necessarily mean that they have lexical relations. The differences are of two kinds, namely consonantal and vocalic:

6-1 Consonantal differences: the most important differences are as follows:

- instead of [b] in standard Persian, [f] , [v] or [m] are sometimes used in Tati Kajal:

Tati Kajal Standard Persian

Âsif sib (apple)

- instead of [d] in standard Persian, [t] , [v] , [z] , [y] and [b] are sometimes used in Tati dialect:

$\begin{array}{lll}\text { Tati Kajal } & \text { Standard Persian } \\ \text { Maččet } & \text { Masjed }\end{array}$

- instead of [v] in Persian, [b] is sometimes used in Kajal:

Tati Kajal Standard Persian

Bafâ Vafâ (loyalty)

- instead of [r] in Persian, [1] is used in Tati dialect:

Tati Kajal Standard Persian

Anjil Anjir (fig)

- instead of [z] in Persian, [j] is used in Tati dialect:

$\begin{array}{lll}\text { Tati Kajal } & \text { Standard Persian } & \\ \text { Tâja } & \text { Tâze } & \text { (new) }\end{array}$

- instead of [j] in Persian, [č] is sometimes used in Kajal:

Tati Kajal Standard Persian

čuwâl Juvâl (a kind of bag)

- instead of [g] in Persian, [v] is sometimes used in Kajal:

Tati Kajal Standard Persian

Varg Gorg (Wolf)

- instead of [x] in Persian, [h] or [j] are sometimes used in Kajal:

$\begin{array}{lll}\text { Tati Kajal } & \text { Standard Persian } & \\ \text { Hošk } & \text { Xošk } & \text { (dry) }\end{array}$

- instead of $[\mathrm{h}]$ in Persian, sometimes [x] and sometimes [v] are used in Kajal dialect:

Tati Kajal Standard Persian

Xana Hanâ (henna)

- instead of [q] in Persian, [x] is sometimes used in Kajal dialect:

Tati Kajal Standard Persian

Vaxt Vaqt (time)

- instead of [n] in Persian, there is sometimes used a group of consonants such as [nd] in Kajal dialect:

Tati Kajal Standard Persian

Sind sen (age)

- instead of consonant group [nb] in Persian, [mb] is sometimes used in Kajal dialect: 
$\begin{array}{ll}\text { Tati Kajal } & \text { Standard Persian } \\ \text { Tambal } & \text { Tanbal (lazy) }\end{array}$

- instead of constant group [nj] in Persian, [mj] is sometimes used in Kajal dialect:

Tati Kajal Standard Persian

Bâdemjân Bâdenjân (eggplant)

- instead of [m] in Persian, [n] is sometimes used in Kajal dialect:

Tati Kajal Standard Persian

Tâmân Tamâm (finish)

- instead of [z] in Persian, [ž] is sometimes used in Kajal dialect:

Tati Kajal Standard Persian

Bežan Bezan (Hit!)

Sometimes the consonant of the coda after the vowel or the coda consonant of some of the consonant clusters in Persian does not exist in Tati Kajal dialect:

\section{Tati Kajal Standard Persian}

ču čub (wood)

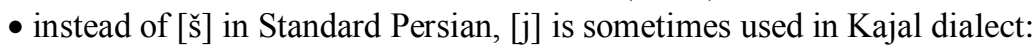

Tati Kajal Standard Persian

čakkuj čakkoš (hammer)

- instead of the consonant group [xt] in Persian infinitives, [t] is sometimes used in Kajal dialect:

Tati Kajal

(to burn)

- like colloquial Persian in Tati dialect [?] and [h] in the medial or final positions are usually deleted and such a deletion is often accompanied by the adjacent long Vowel:

\section{Tati Kajal Standard Persian}

Ja:ba ja?be (box)

- the omission of [h] in some of the words in Tati dialect results in the substitution of [?] and [y] consonants:

Tati Kajal Standard Persian

Ta?ammol tahammol (tolerance)

7) Vocalic differences: the most important vocalic differences between standard Persian and Tati Kajal dialect are as follows:

- instead of standard Persian [a], [â], [e] and [o] are sometimes used in Tati Kajal:

$\begin{array}{lll}\text { Tati Kajal } & \text { Standard Persian } & \\ \text { Âtâš } & \text { ?âtaš } & \text { (fire) } \\ \text { Fendeq } & \text { fandoq } & \text { (hazelnut) } \\ \text { ongušta } & \text { ?angoštar } & \text { (ring) }\end{array}$

- instead of [i] in Persian, [e], [u] or [e:] are sometimes used in Tati dialect:

$\begin{array}{lll}\text { Tati Kajal } & \text { Standard Persian } & \\ \text { yaqen } & \text { yaqin } & \text { (certainly) } \\ \text { šuša } & \text { šiše } & \text { (glass) } \\ \text { me:x } & \text { mix } & \text { (nail) }\end{array}$

- instead of [e] in Standard Persian, [i], [o] and [a] are sometimes used in Kajal dialect:

$\begin{array}{lll}\text { Tati Kajal } & \text { Standard Persian } & \\ \text { tika } & \text { tekke } & \text { (piece) } \\ \text { jigar } & \text { jegar } & \text { (liver) } \\ \text { čolow } & \text { čelow } & \text { (boiled rice) }\end{array}$

Those nouns in Persian that end in the vowel [e] will end in the vowel [a] in Tati dialect:

$\begin{array}{lll}\text { Tati Kajal } & \text { Standard Persian } & \\ \text { Parda } & \text { parde } & \text { (curtain) } \\ \text { nâma } & \text { name } & \text { (letter) }\end{array}$

- instead of [â] in Persian, [a], [o] and [e] are sometimes used in Kajal dialect: 


Tati Kajal
Âčar
Ašqâl
mola
towestân
Pašt
šel
gandem
dik(k) ân
dö
pör
umid
tuffa
pâlâ
tü
sür

Standard Persian
?âčâr
?âs̆qâl
Male
Tâbestân
Pošt
Šol
gandom
dokkân
do
por
omid
tohfe
polow
to
sorx

(spanner)
(trash)
(trowel)
(summer)
(back)
(loose)
(wheat)
(shop)
(two)
(full)
(hope)
(curio)
(boiled rice)
(you)
(crimson)

- instead of [u] in Persian, [o], [ö], [a] or [â] are sometimes used in Tati Kajal dialect:

$\begin{array}{lll}\text { Tati Kajal } & \text { Standard Persian } & \\ \text { tonel } & \text { tunel } & \text { (tunnel) } \\ \text { xon } & \text { xun } & \text { (blood) } \\ \text { pöl } & \text { pul } & \text { (money) } \\ \text { dör } & \text { dur } & \text { (far away) } \\ \text { gisa } & \text { gisu } & \text { (hair) } \\ \text { kana } & \text { kohne } & \text { (old) } \\ \text { paten } & \text { putin } & \text { (boot) } \\ \text { târ } & \text { tur } & \text { (lace) }\end{array}$

- instead of [ow] in Standard Persian, [o], [u], [a] and [â] are sometimes used in Tati dialect:

$\begin{array}{lll}\text { Tati Kajal } & \text { Standard Persian } & \\ \text { rošan } & \text { rowšan } & \text { (light) } \\ \text { jo:har } & \text { jowhar } & \text { (ink) } \\ \text { nu } & \text { now } & \text { (new) } \\ \text { tuba } & \text { towbe } & \text { (repentance) } \\ \text { pâlâ } & \text { polow } & \text { (boiled rice) }\end{array}$

\section{8) Some of the historical Phonological characteristics of Tati Kajal dialect:}

Since Tati is one of the north-western Iranian dialects, many of its phonetic changes and alterations are similar to those of other dialects in the north-west of Iran (Sabzalipour, 2010, P.31). Some of the aforementioned phonetic changes of Tati dialect are as follows:

A) Change; *dv of initial position in the ancient Iran (duv- in ancient Persian writing) into b- such as: bar "in" (*dvar-).

B) Change; *dZ in the ancient Persia (Avestan -z- , -d- in ancient Persia from Indo-European *-g(h)-) into -z- such as Zâmâ "groom", Zân - "Know!".

C) Protection; *V- of initial position in the ancient Iran, such as: Varân "rain", Vâ "wind".

D) Protection; *-S in the ancient Iran (- $\theta$ - in ancient Persia), such as: âsson "iron".

E) Change; *-tsv- in the ancient Iran (Avestan -sp- , -s- in ancient Persia from Indo-European *-Kw) into -sb- or -spSuch as: espaj "louse", esba "dog".

F) Change; *-xt- in the ancient Iran into -t- such as the past tense of the verbs to burn and to sew that are sut- from suxtan and dut- from duxtan respectively in the dialect.

G) Change; -č- in the ancient Iran between two vowels into -j- such as suj- (the present tense of the verb to burn) and duj- (the present tense of the verb to sew).

H) Protection of the ablaut; in this dialect, the ablaut is kept in some of the verbs, for example:

$\begin{array}{ll}\begin{array}{l}\text { Transitive Verb } \\ \text { gârd - ân - əst - an } \\ \text { râs - ân - əst - an } \\ \text { târs - ân - ast - an }\end{array} & \begin{array}{l}\text { Transitive meaning } \\ \text { to take somebody out } \\ \text { to carry } \\ \text { to scare }\end{array} \\ \begin{array}{l}\text { Transitive Verb } \\ \text { gard - ast - an }\end{array} & \begin{array}{l}\text { Transitive meaning } \\ \text { to cruise } \\ \text { ras - ast - an }\end{array} \\ \text { tars - əst - an } & \text { to arrive } \\ & \text { to be afraid }\end{array}$

\section{DisCUSSIONS AND CONCLUSIONS:}

Considering the proposed research question and hypothesis of the research it can be concluded that according to the 
mentioned hypothesis, Tati Kajal dialect is phonetically and phonologically different from Persian. The main differences are as follows:

1- The comparison of the vowels in Persian and Tati dialect shows that there are six vowels in Persian language that are $(\mathrm{a}, \mathrm{e}, \mathrm{o}, \hat{\mathrm{a}}, \mathrm{i}, \mathrm{u})$, but in Tati dialect there are there more distinguishing vowels $(ə, \ddot{o}, \ddot{\mathrm{u}})$ that are totally nine vowels in the dialect.

2- The comparison of the consonants in Persian and Tati dialect indicates that there is no any consonant of glottal stop /?/ in Tati dialect, because it does not have total distribution in the ounset, nucleus and coda of the syllable, but it is sometimes used as mid-vowel. The dialect has also a fricative that is known as voiced Malazi $/ \gamma /$.

3- Comparing the syllables of the two languages (Persian and Tati) indicates that both have six kinds of syllable in the Phonological deep structure that are entirely illustrated as (c) V (c) (c); however, there are the same six kinds of syllable in the phonetic surface structure of Tati dialect, while in Persian there are three syllables in the form of cv (c) (c) that requires an onset in the language.

4 - Comparing Persian with Tati dialect shows that the vowel /a/ is kept in the final position of lexical morphemes in Tati dialect.

5- Comparing Persian with Tati dialect also indicates that the ablaut is protected in some of the verbs.

\section{REFERENCES}

[1] Sabzalipour, Jahandoust. (2010). Tati Language (The description of Tati dialect of Roodbar). Rasht: Iliya Farhang.

[2] Safarzadeh, Habib. (2003). Tati Dialect of the Northen Khorasan. Mashhad: Sokhangostar.

[3] Spolsky, Bernard. (1998). Sociolinguistics. Oxford University Press. Bristol, U.K.

[4] Yarshatter Ehsan. (1969). A Grammer of Southern Tati Dialects. Paris: The Hague.

[5] Yarshatter Ehsan. (1957). Iranian Languages and Accents. The magazine of the faculty of literature, Tehran University, the fifth year no. $1 \& 2$, PP. $11-46$.

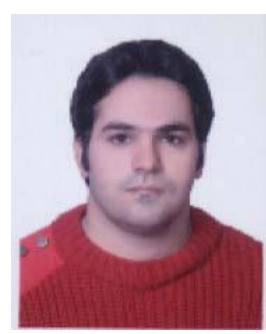

Mohammad Asadi was born in Tehran, Iran in May $5^{\text {th }}, 1982$. He acquired the B.A. of Hausa Language and Literature from Azad University, in 2006. He received his M.A. in Linguistics from Islamic Azad University, Science \& Research Branch in 2011, Tehran, Iran.

He works now as an English Teacher in kalam language Institute, Tehran; Talieh kamal Elm Institute, Tehran; Sayi simin Institute, Tehran and Iran-Europe Language Institute Tehran, Iran.

He has published an article (as corresponding author) titled "The Contrastive Analysis of Gender Factor Manifestation in the language of Advertisement in Iran in 1980's and 2000's" in International Journal of Humanities and Social Science in 2012, Vol. 2: 151-158.

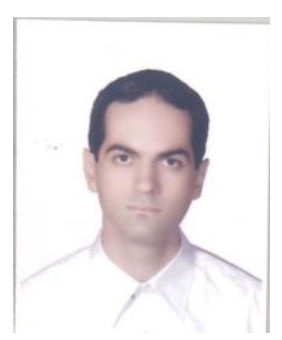

Mehdi Bagheri Hariry was born in Tehran, Iran in August $24^{\text {th }}$, 1979. He acquired the B.A. of English Language Translation from Payame Noor University, Tehran in 2005. He received his M.A. in translation studies from Islamic Azad University, Science \& Research Branch in 2010, Tehran, Iran.

He works now as an English Teacher/Professor in kalam language Institute, Tehran; Iran-Mehr (N.B.E) Language Institute, Tehran; Hermes Language Institute, Tehran and Payame noor University, Bagher-Shahr Branch, Iran.

He has published an article (as second author) titled "The Contrastive Analysis of Gender Factor Manifestation in the language of Advertisement in Iran in 1980's and 2000's" in International Journal of Humanities and Social Science in 2012, Vol. 2: 151-158.

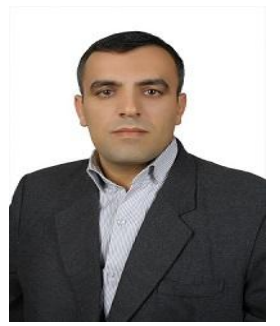

Razzagh Kiyani was born in Khalkhal, Iran in Apr. $4^{\text {th }}, 1977$. He acquired the B.A. of English Language and Literature from Azad University, in 2004. He received his M.A. in Linguistics from Islamic Azad University, Science \& Research Branch in 2011, Tehran, Iran.

He works from 2002 to present as an English Teacher in Sina English Institute, Tehran, Iran. 